\title{
Anammox bacteria detected in fish intestinal tract systems
}

\author{
Ho Wang Chan, Han Meng and Ji-Dong Gu* \\ Laboratory of Environmental Toxicology, School of Biological Science, The University of Hong Kong, Pokfulam Road, \\ Hong Kong SAR, People’s Republic of China
}

\begin{abstract}
Anammox bacteria serve an important ecological role in the global nitrogen cycle, enabling the coupling of ammonium and nitrite to yield dinitrogen gas $\left(\mathrm{N}_{2}\right)$ under anoxic conditions. Based on PCR amplifications of genomic DNA and analysis of the 16S rRNA gene sequence, anammox bacteria was found in intestinal tracts of two types of fish, Siganus fuscescens and Mugil cephalus. Anammox bacteria identified in these fish belonged to the genera Brocadia and Kuenenia, suggesting that the living conditions of $S$. fuscescens and $M$. cephalus were under significant influence of wastewater pollution. Our results showed an association between the existence of anammox bacteria in fish intestinal tracts and sediment- or mud-eating habits of the fish involved. The presence of anammox bacteria in an animal system would provide a more comprehensive understanding on ecophysiological characteristics and distribution of anammox bacteria. This discovery might also provide useful information about the living conditions of fish, serving as an environmental indicator of anthropogenic pollution.
\end{abstract}

Keywords: anammox, fish gut, Siganus fuscescens, Mugil cephalus, black rabbit fish, flathead mullet

*Correspondence to: Ji-Dong Gu, Laboratory of Environmental Toxicology, School of Biological Science, The University of Hong Kong, Pokfulam Road, Hong Kong SAR, People’s Republic of China; Email: jdgu@hku.hk

Received: October 21, 2015; Accepted: March 8, 2015; Published Online: April 8, 2016

Citation: Chan H W, Meng H and Gu J-D, 2016, Anammox bacteria detected in fish intestinal tract systems. Applied Environmental and Biotechnology, vol.(1): 13-18. http://dx.doi.org/10.26789/AEB.2016.01.010.

\section{Introduction}

A naerobic ammonia oxidation, or anammox, is a novel pathway in the nitrogen cycle which was discovered in $1995^{[1]}$. This pathway is governed by a group of microorganisms known as the anammox bacteria. Nitrite $\left(\mathrm{NO}_{2}{ }^{-}\right)$and ammonium $\left(\mathrm{NH}_{4}{ }^{+}\right)$would be used as substrates and $\mathrm{N}_{2}$ gas would be released as the final product. Anammox bacteria serve a significant role in the ecological niche of the global nitrogen cycle. To date, 5 genera of anammox bacteria have been described, and all of them areaffiliated with a deep branch of the phylum Planctomycetes. The 5 genera include Candidatus Scalindua ${ }^{[2]}$, Ca. Brocadia ${ }^{[3]}$, Ca. Anamoxoglobus ${ }^{[4]}$, Ca. Jettenia ${ }^{[5]}$, and $C a$. Kuenenia ${ }^{[6]}$. Anammox bacteria are still described as 'Candidatus', which means that no pure culture of anammox bacteria could be obtained. Due to the unavailability of pure culture and slow growth rates of anammox bacteria ${ }^{[3]}$, many studies on anammox bacteria are widely based on culture-independent methods.

Anammox bacteria have been identified in highly diverse ecosystems including marine sediments ${ }^{[7]}$, rice paddy fields ${ }^{[8]}$, coastal wetlands ${ }^{[9]}$, fresh water terrestrial ecosystems ${ }^{[10-12]}$, oil fields ${ }^{[13]}$, and wastewater sludges $^{[5]}$. Out of the 5 genera of anammox bacteria, Ca. Scalindua is generally related to environments with low nitrogen content such as sediments from unpolluted marine environments. The other 4 genera are

Anammox bacteria detected in fish intestinal tract systems. (c) 2016 Ho Wang Chan, et al. This is an Open Access article distributed under the terms of the Creative Commons Attribution-NonCommercial 4.0 International License (http://creativecommons.org/licenses/by- nc/4.0/), permitting all non-commercial use, distribution, and reproduction in any medium, provided the original work is properly cited. 
more related to environments with abundant nitrogen sources such as wastewater treatment facilities and sediments from polluted estuaries. Hence, anammox bacteria could be a bio-indicator for anthropogenic nitrogen input ${ }^{[14,15]}$.

Although anammox bacteria have been identified in a huge variety of environments, they have not been reported in fish intestines so far. To trace anammox bacteria, it is important to find both reactive nitrogen species as well as anoxic environments. In animal intestines, reactive nitrogen such as ammonia could be produced via microbial activities ${ }^{[16]}$. Intestinal tracts also provide anaerobic conditions which is essential for the establishment of anammox bacteria. Recently, molecular evidence on the existence of anammox bacteria in the gut of polychaetes has been found (Meng Li and Ji-Dong Gu 2014, unpublished results). Therefore, the association between anammox bacteria and animal gut was proposed. In this study, we investigated the existence and type of anammox bacteria in fish intestines using PCR-based techniques.

In this project, we selected fish as the target of investigation. Thus, a nitrogen source would be more readily available and would enhance the chances of anammox bacteria to exist in fish intestines. Moreover, fish are generally small in size and are hence easy to handle. Fish samples were collected from different environments; therefore, we were able to analyze the relationship between living conditions, feeding habits, and the type of anammox bacteria in fish intestines.

\section{Materials and Methods}

We investigated six different species of fish in this study. The brief summary of species used is listed in Table 1.

In this experiment, all fish were bought from the local fish market. During dissection, the gut of each fish was isolated and its intestinal contents were squeezed out and collected. The gut content was then grounded to a sticky fluid using a sterile plastic rod. After grinding, the sample mass was weighed and we extracted the DNA using E.Z.N.A. ${ }^{\circledR}$ Forensic DNA Kit (Omega Bio-tek, USA), following bacterial DNA protocol extraction from biological fluids. The concentrations and purity of the DNA samples were examined using a Nanodrop spectrophotometer.

We used the extracted DNA for PCR amplification. In a total volume of $25 \mu \mathrm{L}$, the PCR reaction mixture contained: $2 \mu \mathrm{L}$ DNA templates $(0.1-1.0 \mu \mathrm{g} / \mu \mathrm{L}), 12.5 \mu \mathrm{L}$ Premix Taq Version 2.0 (TaKaRa, Japan), $2 \mu \mathrm{L}$ of each forward and reverse primers $(10 \mu \mathrm{M}), 2 \mu \mathrm{L} \mathrm{MgCl}_{2}$ (25 mM, Promega, Hong Kong), and $4.5 \mu \mathrm{L}$ sterile distilled deionized water. In this study, we selected primer set amx438f/amx684r to detect the 16S rRNA gene of anammox bacteria. This set of primer was selected as it was found to be effective when dealing with a collection of samples with various physiochemical properties ${ }^{[17]}$. For negative result samples (no anammox bacteria detected), we used the universal primer set $27 \mathrm{f} / 536 \mathrm{r}$ to examine the validity of the extracted DNA. Detailed information of primers is listed in Table 2.

Table 1. Fish species analyzed in this study

\begin{tabular}{llccl}
\hline \multicolumn{1}{c}{ Species Name } & \multicolumn{1}{c}{ Common Name } & Seawater/Fresh water & Wild/Cultured & \multicolumn{1}{c}{ Food Source } \\
\hline Nemipterus virgatus & Golden threadfin bream & Seawater & Wild & Small fish, Shrimp \\
Siganus fuscescens & Black rabbit fish & Seawater & Wild & Algae, Crustacean, Suspended solid \\
Ablennes hians & Flat needlefish & Seawater & Wild & Plankton \\
Mugil cephalus & Flathead mullet & Freshwater & Cultured & Artificial feed, Sediment \\
Carassius auratus & Edible goldfish & Freshwater & Cultured & Artificial feed \\
Siniperca chuatsi & Mandarin fish & Freshwater & Cultured & Artificial feed \\
\hline
\end{tabular}

Table 2. Summary of PCR primers sets used in this study

\begin{tabular}{|c|c|c|c|c|c|}
\hline Primer & 5'-3' sequence & Fragment size (bp) & Thermal profile & Specificity & Reference \\
\hline Amx438f & GTCRGGAGTTADGAAATG & \multirow{2}{*}{246} & \multirow{2}{*}{$\begin{array}{l}95^{\circ} \mathrm{C}, 5 \mathrm{~m} ; 35 \times\left(95^{\circ} \mathrm{C}, 30 \mathrm{~s} ; 55^{\circ} \mathrm{C} \text {, }\right. \\
\left.30 \mathrm{~s} ; 72^{\circ} \mathrm{C}, 30 \mathrm{~s}\right) ; 72^{\circ} \mathrm{C}, 7 \mathrm{~m}\end{array}$} & \multirow{2}{*}{$\begin{array}{l}\text { 16s rRNA gene, anam- } \\
\text { mox bacteria }\end{array}$} & \multirow{2}{*}[17]{} \\
\hline Amx684r & ACCAGAAGTTCCACTCTC & & & & \\
\hline $27 f$ & AGAGTTTGATCMTGGCTCAG & \multirow{2}{*}{511} & \multirow{2}{*}{$\begin{array}{l}95^{\circ} \mathrm{C}, 5 \mathrm{~m} ; 35 \times\left(95^{\circ} \mathrm{C}, 30 \mathrm{~s} ; 53^{\circ} \mathrm{C} \text {, }\right. \\
\left.45 \mathrm{~s} ; 72^{\circ} \mathrm{C}, 45 \mathrm{~s}\right) ; 72^{\circ} \mathrm{C}, 7 \mathrm{~m}\end{array}$} & \multirow{2}{*}{$\begin{array}{l}\text { 16s rRNA gene, } \\
\text { all bacteria }\end{array}$} & [18] \\
\hline $536 r$ & GTATTACCGCGGCTGCTGG & & & & [19] \\
\hline
\end{tabular}


Ho Wang Chan, Han Meng and Ji-Dong Gu

We analyzed the PCR products via electrophoresis in $1 \%$ agarose gels in TAE buffer at $130 \mathrm{~V}$ for $25 \mathrm{~m}$. GelRed nucleic acid stain (Biotium) was added into the gel in a volume ratio of 1 to 20,000; gels were photographed using Bio-Rad® GelDocTM station.

We purified the amplified DNA fragments using a Qiaex II Gel Extraction Kit (QIAGen, Hilden, Germany) and ligated the amplified fragments to $\mathrm{pMD}{ }^{\circledR}$ 18 -T vectors (TaKaRa, Japan). In the ligation step, 0.3 $\mu \mathrm{L}$ of $\mathrm{pMD}{ }^{\circledR} 18-\mathrm{T}$ vector, $5 \mu \mathrm{L}$ of solution 1 containing T4 DNA ligase, and ligation buffer was mixed with $4.7 \mu \mathrm{L}$ of the purified DNA for a total reaction mixture of $10 \mu \mathrm{L}$. Ligation was performed at $16^{\circ} \mathrm{C}$ for 3 hours. After ligation, the T-vectors were transferred into E. coli DH5 $\alpha$ competent cells (TaKaRa, Japan) and were spread on LB plate containing ampicillin sodium salt at a concentration of $100 \mu \mathrm{g} / \mathrm{mL}$ (SigmaAldrich, USA). LB plates were then incubated in $37^{\circ} \mathrm{C}$ for 12 hours. Clones were randomly selected for sequencing.

After sequencing, the data were imported into BioEdit software, the T-vector component in the sequence was trimmed and the processed sequences were analyzed using the BLAST program (Basic Local Alignment Search Tool) from the National Center for Biotechnology Information (NCBI). Finally, the 16S rRNA gene sequence of the 5 anammox bacteria genera were downloaded from NCBI's database and imported with testing sequences into MEGA version 6.0. We constructed phylogenetic trees to distinguish the genera of the anammox bacteria found in the fish gut in this study.

\section{Results}

The primer set amx438f/amx684r yielded positive results for samples collected from flathead mullet (2 out of 4 samples) and black rabbit fish (3 out of 4 samples), while all other samples generated negative results for the detection of anammox. For samples giving negative results, we repeated the PCR amplification using a universal primer set 27f/536r to test its validity. Samples from edible goldfish and mandarin fish yielded positive results while samples from golden threadfin bream and flat needlefish yielded negative results. A brief summary of the PCR result is listed in Table 3.

We sequenced the amplified DNA samples of anammox positive results and compared it with NCBI's database (samples B2 and B4 collected from flathead mullets; samples M4, M7, and M8 collected from
Table 3. A brief summary of the PCR amplification results

\begin{tabular}{lccc}
\hline \multicolumn{1}{c}{ Species } & $\begin{array}{c}\text { Number of } \\
\text { samples tested }\end{array}$ & $\begin{array}{c}\text { Amx438f/ } \\
\text { Amx684r }\end{array}$ & 27f/536r \\
\hline Golden threadfin bream & 6 & - & - \\
Black rabbit fish & 4 & + & N/A \\
Flat needlefish & 2 & - & - \\
Edible Goldfish & 4 & - & + \\
Flathead mullet & 4 & + & N/A \\
Mandarin fish & 1 & - & + \\
\hline
\end{tabular}

black rabbit fish). Sequences collected from sample B2 did not show any significant results with the available sequences in the database. On the other hand, sequences from B4, M4, M7, and M8 all showed high similarities with the 16S rRNA gene sequence of anammox bacteria. In total, we selected 10 sequences with high similarities (98-100\% identical to anammox bacteria gene in the database) to construct a phylogenetic tree. From the phylogenetic tree constructed (Figure 1); in both samples from flathead mullets and black rabbit fish, we observed genes from $\mathrm{Ca}$. Brocadia and $\mathrm{Ca}$. Kuenenia.

\section{Discussion}

In this section, the experimental result would be interpreted and the significance would be discussed briefly. First, the results obtained from PCR amplifications and sequencing prove that anammox bacteria genes are present in gut materials of some species of fish, providing molecular evidence on the existence of anammox bacteria in fish intestines. Furthermore, anammox bacteria could be observed in the gut of fish from both wild (black rabbit fish, seawater) and cultured (flathead mullets, freshwater) environments.

Out of the 6 species tested, anammox bacteria could only be detected in the gut of black rabbit fish and flathead mullets. This may be attributed to the feeding style of these species. A common characteristic observed in these two species is that both have a habit of eating organic silt, mud, sediment, or fecal matter ${ }^{[20,21]}$, which are all possible sources of anammox bacteria.

In Hong Kong, black rabbit fish is commonly caught in coastal areas especially around the sewage pipes. Hence, apart from algae and small invertebrates, black rabbit fish also commonly feed on suspended solids and faecal matter from the sewage discharge. As suspended solids usually contain considerable amounts of ammonia and oxygen levels in sewage discharge is usually low due to the decomposition of organic load, 


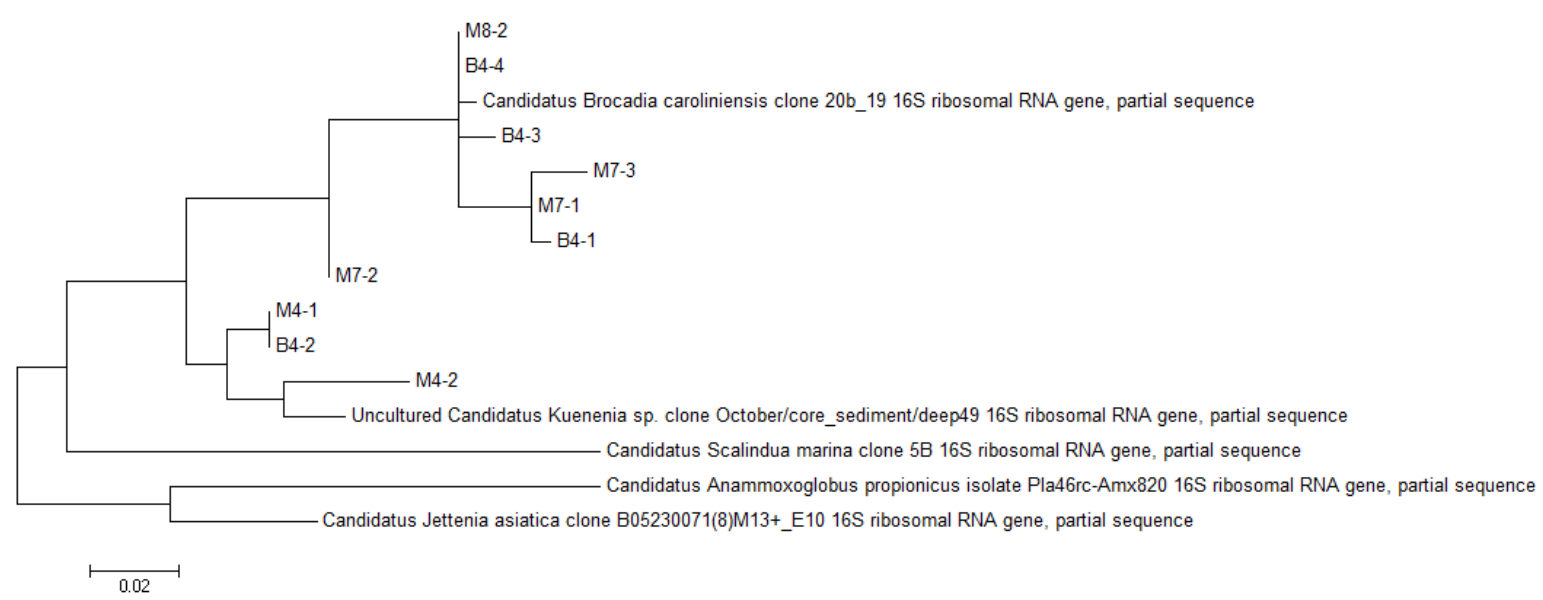

Figure 1. Phylogenetic tree constructed with neighbor-joining method from an alignment of the 16S rRNA gene.

anammox bacteria is probably found in the suspended solids. By ingesting these suspended solids, anammox bacteria may enter the intestinal tracts of black rabbit fish.

Flathead mullets are usually co-cultured with other species (e.g. carp, edible goldfish) in local freshwater fish farms ${ }^{[21]}$. Thus, fish in culture would basically share the same artificial feed. However, other than artificial feed, flathead mullets also eat sediments at the bottom of the lake. As anammox bacteria can only be found in the gut of flathead mullets but not in other fish from cultural environments (i.e. edible goldfish and mandarin fish), and the results from the universal primer test suggested that the negative results produced from edible goldfish and mandarin fish samples were valid; thus the presence of anammox bacteria in the gut of flathead mullets may be attributed to its sediment-eating habits.

According to the phylogenetic tree constructed, two genera of anammox bacteria, namely $\mathrm{Ca}$. Brocadia and $\mathrm{Ca}$. Kuenenia were discovered in the gut material of fish. Both $C a$. Brocadia and $C a$. Kuenenia are genera that are more closely related to polluted water systems and these results are in agreement to the living environments of these fish. As mentioned above, black rabbit fish are usually caught from the waters near wastewater discharge. In fish farming practices, flathead mullets are usually cultured in an enclosed water system with a high population density. As such, the water systems would contain considerable amounts of metabolic wastes and feed debris, in turn providing plentiful reactive nitrogen sources. Hence, the high nitrogen contents in living environments of black rabbit fish and flathead mullets would encourage the development of $\mathrm{Ca}$. Brocadia and Ca. Kuene- nia in those environments. Through food intake, these anammox bacteria may be ingested, reaching the intestinal tracts of fish and are thus detected.

All samples collected from the other species studied in this project (golden threadfin bream, flat needlefish, edible goldfish, and mandarin fish) yielded negative results using the primer set amx438f/amx684r. To check the validity of the DNA samples, a universal primer was applied. In this test, samples of edible goldfish and mandarin fish gave positive results, suggesting that the DNA sample was valid. Hence, the negative results in anammox bacteria detection should be a true negative.

However, samples of golden threadfin bream and flat needlefish gave negative results in the universal primer test, suggesting that the DNA sample was invalid. Thus, it is only probable to state that anammox bacteria genes were not amplified in these samples but it is inappropriate to determine whether anammox bacteria is present or absent in the samples. Negative results together with low DNA concentration in the extraction may imply that the DNA extraction method applied was not very effective in dealing with the samples from golden threadfin bream and flat needlefish. In future studies, it may be necessary to explore modifications in the DNA extraction methods.

This is the first time that the presence of anammox bacteria was reported in fish gut. This may provide us a more comprehensive understanding on the diversity and distribution of anammox bacteria in the natural environment. Moreover, as the type and community of anammox bacteria would be affected by nitrogen content in the environment, in other words, its cleanliness ${ }^{[15]}$, the presence of anammox bacteria in fish gut may provide some information about the environmen- 
tal status in which the fish is currently experiencing. Hence, anammox bacteria in fish gut may serve as an environmental indicator to estimate the environmental conditions of its living environment.

However, since only a preliminary investigation has been carried out, there are many questions that require further scrutinizing. For example, although molecular evidences showed the presence of anammox bacteria in fish gut, further studies are needed to distinguish whether anammox bacteria are transient or resident flora in fish intestines. Furthermore, as the nutrient levels in the surrounding environment would change along the fish intestines, difference clusters of anammox bacteria may be found in different sections of the gut. The current DNA extraction method may not be very effective for some samples; modifications in the extraction methods may be required in further studies.

\section{Conclusion}

Anammox bacteria were first identified in the gut of Siganus fuscescens and Mugil cephalus respectively. The identified anammox bacteria in fish gut belong to the genera Brocadia and Kuenenia, which are both related to relatively polluted water systems. These experimental results may suggest a relationship between sediment-eating habits and the presence of anammox bacteria. These findings may provide a more comprehensive understanding to the diversity and distribution of anammox bacteria in the natural environment. However, as this project is a pilot study, various kinds of detailed follow-up research would be necessary in the future.

\section{Conflict of interest and Funding}

The authors declared no potential conflict of interest with respect to the research, authorship, and/or publication of this article. This project was supported by the Hong Kong PhD Fellowship (HM) and RGC GRF grant No. 701913 (J-DG). Additional financial support for this research project was from the laboratory fund.

\section{Acknowledgements}

We thank Ms. Kelly Lau for her general laboratory assistance.

\section{References}

1. Mulder A,Vandegraaf A A, Roberson L A, et al. 1995, Anaerobic ammonium oxidation discovered in a denitrifying fluidizied-bed reactor. FEMS Microbiology
Ecology, vol.16(3): 177-183.

http://dx.doi.org/10.1016/0168-6496(94)00081-7.

2. Schmid M, Walsh K, Webb R, et al. 2003, Candidatus

"Scalindua brodae", sp.nov., Candidatus "Scalindua wagneri”, sp.nov., two new species of anaerobic ammonium oxidation bacteria, Systematic Applied Microbiology, vol.26(4): 529-538.

http://dx.doi.org/10.1078/072320203770865837.

3. Strous M, Kuenen J G, and Jetten M S, 1999, Key physiology of anaerobic ammonium oxidation. Applied Environmental Microbiology, vol.65: 3248-3250.

4. Kartal B, Rattray J, Van Niftrik L et al. 2007, Candidatus “Anammoxoglobus propionicus" gen. nov., sp. nov., a new propionate oxidizing species of anaerobic ammonium oxidizing bacteria. Systematic Applied Microbiology, vol.30(1): 39-49.

http://dx.doi.org/10.1016/j.syapm.2006.03.004.

5. Quan Z X, Rhee S K, Zuo J E, et al. 2008, Diversity of ammonium-oxidizing bacteria in granular sludge anaerobic ammonium-oxidizing (anammox) reactor. Environmental Microbiology, vol.10(11): 3130-3139. http://dx.doi.org/10.1111/j.1462-2920.2008.01642.x.

6. Schmid M, Twachtmann U, Klein M, et al. 2000, Molecular evidence for genus level diversity of bacteria capable of catalyzing anaerobic ammonium oxidation. Systematic Applied Microbiology, vol.23(1): 93-106. http://dx.doi.org/10.1016/S0723-2020(00)80050-8.

7. Schmid M C, Risgaard-Petersen N, van de Vossenberg J, et al. 2007, Anaerobic ammonium-oxidizing bacteria in marine environments: widespread occurrence but low diversity. Environmental Microbiology, vol.9(6): 14761484.

8. Wang J and Gu J-D, 2012, Dominance of Candidatus Scalindua species in anammox community revealed in soils with different duration of rice paddy cultivation in Northeast China. Applied Microbiology and Biotechnology, vol.97: 1785-1798.

http://dx.doi.org/10.1007/s00253-012-4036-x.

9. Risgaard-Petersen N, Meyer R L, Schmid M, et al. 2004, Anaerobic ammonium oxidation in an estuarine sediment. Aquatic Microbial Ecology, vol.36(3): 293-304. http://dx.doi.org/10.3354/ame036293.

10. Penton C R, Devol A H, and Tiedje J M, 2006, Molecular evidence for the broad distribution of anaerobic ammonium-oxidizing bacteria in freshwater and marine sediments. Applied Environmental Microbiology, vol.72(10): 6829-6832. http://dx.doi.org/10.1128/AEM.01254-06.

11. Lee K H, Wang Y F, Li H, et al. 2014, Niche specificity of ammonia-oxidizing archaeal and bacterial communities in a freshwater wetland receiving municipal waste- 
water in Daqing, Northeast China. Ecotoxicology, vol.23(10): 2081-2091.

http://dx.doi.org/10.1007/s10646-014-1334-3.

12. Lee K H, Wang Y F, Zhang G X, et al. 2014, Distribution patterns of ammonia-oxidizing bacteria and anammox bacteria in the freshwater marsh of Honghe wetland in Northeast China. Ecotoxicology, vol.23(10): 1930-1942.

http://dx.doi.org/10.1007/s10646-014-1333-4.

13. Li H, Chen S, Mu B Z, et al. 2010, Molecular detection of anaerobic ammonium-oxidizing (anammox) bacteria in high-temperature petroleum reservoirs. Microbial Ecology, vol.60(4): 771-783. http://dx.doi.org/10.1007/s00248-010-9733-3.

14. Li M, Hong Y G, Cao H L, et al. 2013, Using the variation of anammox bacteria community structures as a bio-indicator for anthropogenic or terrestrial nitrogen inputs in the Pearl River Delta (PRD). Applied Microbiology and Biotechnology, vol.97(22): 9875-9883. http://dx.doi.org/10.1007/s00253-013-4990-y.

15. Han P and Gu J-D, 2015, Further analysis of anammox bacterial community structures along an anthropogenic nitrogen-input gradient from the riparian sediments of the Pearl River Delta to the deep-ocean sediments of the South China Sea. Geomicrobiology Journal, vol.32(9): 789-798. http://dx.doi.org/10.1080/01490451.2014.1001502.
16. Vince A J, Burridge S M, 1980, Ammonia production by intestinal bacteria: the effects of lactose, lactulose and glucose. Journal of Medical Microbiology, vol.13(2): 177-191. http://dx.doi.org/10.1099/00222615-13-2-177.

17. Han P, Huang Y T, Lin J G, et al. 2013, A comparison of two 16S rRNA gene-based PCR primer sets in unraveling anammox bacteria from different environmental samples. Applied Microbiology Biotechnology, vol.97(24): 10521-10529.

http://dx.doi.org/10.1007/s00253-013-5305-z.

18. Lane D J (eds) 1991, 16S/23S rRNA sequencing, in Nucleic Acid Techniques in Bacterial Systematics. John Wiley and Sons, New York: 115-175.

19. Giovannoni S J, DeLong E F, Olsen G J, et al. 1988, Phylogenetic group-specific oligodeoxynucleotide probes for identification of single microbial cells. Journal of Bacteriology, vol.170(2): 720-726.

20. Sadovy Y and Cornish A S, 2000, Rabbitfishes, Siganidae, in Reef Fishes of Hong Kong. Hong Kong University Press, Hong Kong: 262-264.

Agricultural, Fisheries and Conservation Department, HKSAR, 2015, Marine fish culture, pond fish culture and oyster culture, viewed May 20, 2015,

<http://www.afcd.gov.hk/english/fisheries/fish_aqu/fish _aqu_mpo/fish_aqu_mpo.html> 